\title{
Gleason Grade Group 1
}

National Cancer Institute

\section{Source}

National Cancer Institute. Gleason Grade Group 1. NCI Thesaurus. Code C137992.

Only individual discrete well-formed glands. 